\title{
Adam Kaczmarski
}

Training Team; Personnel and Training Department;

Municipal Police Headquarters in Bydgoszcz, Poland

\section{Organization of the Shooting Training System in the Polish Police}

\section{Abstrakt}

The police is one of the public administration bodies that has a statutory task to provide citizens with security, also in an armed way. The article presents the organization and format of the current Polish police shooting training system. Based on the results of previous studies, it was pointed out that training courses and practice sessions carried out by the police officers are more important than their individual personality traits. Implementation trainings reflecting real situations would help to improve the level of police officers' preparation for work.

Keywords: shooting training, firearms, training system in the Police, Police

Creating the English-language version of the journal "Securitologia" is financed under contract No. 724/P. DUN/2018 from the funds allocated by the Minister of Science and Higher Education for dissemination of science. 


\section{Introduction}

In sociological terms, a person living in a certain community is defined as a being or a social unit that is not capable of independent functioning or proper development - without the participation of third parties (Aronson 1997; Gołdyka et al. 1999). For a human being, being part of the community gives a chance for survival, and therefore defining a contemporary man in a proper and comprehensive way can only be successful if the civilization conditions are secured to shape and develop him, both individually and socially. One of the main components of these conditions is to meet the needs that are generated by man himself. Abraham Maslow (1943) showed it in a very precise way in his work The Theory of Man's Motivation. He expressed human needs in the form of a pyramid, stressing that man is able to pursue and satisfy the needs of a higher order only after satisfying the basic pyramid foundations and constituting a solid foundation of the whole structure. The basic physiological needs on the lower segments of the Maslow pyramid include the need for security, and therefore the sense of inner peace is one of the fundamental human needs, opening the way to building family relationships, professional relationships or self-fulfillment.

The security of human community and the human as a member of this community is a very broad concept and can take various forms, ranging from the security of the state against external threats (Walt 1987), economic security, accident protection (eg in the form of established road code rules), against illness (eg a medical care system) or, finally, a sense of mental and personal security of a single individual. The sense of security of each person may include such components as: freedom of speech, freedom of religion, freedom from deprivation and fear, and finally the right to a dignified life (Hofreiter 2013).

In a similar way as the types of security needs, one can distinguish between forms, mechanisms and ways of satisfying them. For the personal safety of a person, defined here as the protection of the individual's goods and property, as well as the inviolability of his health and life, a man can take care of in a large measure in his own, recognized by himself, scope. This can be done, for example, by choosing safe infrastructural spaces for life, such as monitored, gated housing estates, acquiring self-defense skills or possession of weapons for personal protection purposes, in extreme cases even firearms. However, it is difficult to imagine that man would be able to secure himself a peaceful 
existence in a world filled with anarchy, so his participation in society, functioning as a part of it plays a key role here. In this way, he becomes fully dependent on stateorganized forms responsible for ensuring security, such as the services responsible for public safety, while trusting that they will enable him to live unhampered life every day.

One of such organized forms is undoubtedly the police - uniformed and armed formation, legally intended, inter alia, to maintain security, protect human life and health against unlawful attacks on these goods. It is not without significance that in the first words of the Act on the Police, as the supreme legal act regulating the functioning of this institution, we read that it is armed (Ustawa $z$ dnia 6 kwietnia 1990 r. o Policji). It should be understood, therefore, that in order to effectively protect and ensure the safety of people, the police must, in extreme cases, do so in an armed manner. The arming of the police is part of a catalog of direct coercion measures that should be used or used in a way that causes the least possible damage.

Nevertheless, it is a special measure, distinguished by its specificity, and its use can cause innumerable effects and consequences. Since according to the binding legal and social norms, not every citizen can become a fully-fledged owner of a firearm, the fact of having it on the equipment of police officers makes them privileged and distinguished. On the other hand, having a weapon makes them responsible for the trust of society entrusted to them. It is expected that in a situation that absolutely requires it, police officers will use it in a fully professional, correct and, above all, reasonable and safe for innocent participants of the event.

Although in recent years we can observe a decrease in threats resulting from broadly understood criminal activity in Poland, the number of incidents and cases of the use of firearms remains at an exceptionally high level. The average from 2006 to 2016 amounted to 575 crimes per year, using firearms, including homicide, robbery crimes or rape, with as many as 996 recorded in 2016 alone (Statystyka - Policja). The perpetrators of serious criminal crimes are often marked by ruthlessness, which, combined with the desire to achieve their intentions and avoid punishment for their actions, makes them easily reach for firearms or other objects dangerous to life and health. This behavior of criminals in many cases determines police officers to reach for an adequate measure of direct coercion which is a professional firearm. As mentioned above, a commercial firearm is the ultimate tool, and its use can only take place when other means of direct coercion prove insufficient or their use is not possible due to the conditions. However, 
one should not forget that firearms are a lethal tool, and therefore using it in a safe way requires the policeman's knowledge and skills developed during many hours of training.

The article below will discuss the shooting training system for the Polish police in force. The organization as well as the form of shooting instruction will be described separately. In addition, based on previous research, an attempt will be made to answer the question whether the effectiveness of the conducted shooting training is affected by the individual personality, predispositions of the police officers. Detailed characterization of each element, which the training system consists of, can bring the structure of police courses closer and show their good sides and weaknesses. In addition, it can also indicate the direction of changes in the future planning of the police officers' training path, so that they are professional, in line with the expectations of the public, as well as the policemen themselves, and above all, effective in the fight against crime.

\section{Organization of Shooting Training}

The organization of shooting training in the police has a strictly defined structure (Bohdziewicz 2013; Klich 2016). They are divided into two main training areas. The first of them is the so-called vocational training, from which we can in turn distinguish basic vocational training and vocational training for university graduates, colloquially called an "officerka" (officer training) (Martyniak-Mróz 2007). The second branch of training, in which police officers participate, apart from vocational training, is perfecting training, which can be carried out both at the central and local level (Dworzecki 2011). The organization of the central form of professional development, in the form of all kinds of specialist courses, is dealt with by the police schools. Local professional development involves officers to participate in numerous trainings organized and carried out most often in their own organizational units, in which they perform their duties on a daily basis. The forms and scope of the above-mentioned training measures are fundamentally different, although they play an important role in the functioning of the police as an organization, as well as the daily work of the officers focusing on it.

The shooting training of police officers is included in each of the above-mentioned branches of police training. The officers participating in the process of shooting training, throughout their entire service, acquire, improve, consolidate their knowledge and 
skills in the use of firearms. Often, people emerge from them with even greater involvement and the need to broaden their horizons, going beyond the framework of the ways of using firearms. Unfortunately, we can observe, on the other hand, even more numerous police officers who do not aspire to achieve the minimum level, which in real conditions can decide on the result of interventions and, most importantly, the safety of themselves and citizens.

An extreme cases, however, which raises considerable doubts are policemen, using medical exemptions only and precisely only exemptions from the shooting training course. Fortunately, these are marginal cases, but may affect the functioning of the police as a whole. It is difficult to explain the police action as efficient and evoking social trust in a situation where the use of firearms on the scene would occur precisely on the part of an officer who was regularly dismissed by the doctor from participation in shooting training and did not refresh these skills for the last few years.

A very important element of a well-conducted shooting training is the staff who organize and implement these trainings and are obliged to take care of their proper level. Police shooting instructors, wanting to inspire, teach and require the right level of skills in the use of firearms from the participants of their training, should constantly, with even greater intensity and consistency, take care of raising their own craftsmanship. Meanwhile, the element working to the disadvantage of a high level of training is the fact that in local police units throughout the country, the function of a police shooting instructor is usually performed by officers who perform these tasks in an ad hoc manner. They perform various functions on a regular basis in the staffing structure, from policemen of patrol and intervention cells, through district police, detectives of criminal service, to policemen occupying managerial positions. Often there is a lack of adequate motivation and commitment from instructors approaching this task as to the implementation of commissioned work, on the other hand often encountering irritation from their direct superiors, dissatisfied due to the additional work of subordinates, taking the time needed to implement other police activities (Bohdziewicz 2013).

It should not be forgotten that the same instructor, who is obliged to issue binding orders, commands, and directly decides about the completion of the shooting, does not cease to be a "desk colleague", "patrol partner" or "subordinate" every day. This may call into question the quality and accuracy of the knowledge and skills in the use of weapons, as well as the reliability of its verification. 
In addition, one of the most important elements of the organization of the policemen' shooting training system are all applicable legal regulations and procedures. After analyzing the regulations related to police officers' duties regarding participation in shooting training, culminating in periodic tests, it turns out that there are no consequences, such as failing of these shooting tests (Decyzja nr 713; Wytyczne nr 1). Such gaps in the system seriously call into question whether citizens have the right to feel safe, if the only examination verifying the usefulness of a policeman to serve is an exam at the basic course stage. As the law and professional practice in the police show, for the next several or several dozen years of policeman's work, knowledge and shooting skills are verified by means of shooting tests, but not receiving a credit does not determine the suitability of a police officer.

The verification of the strengths and weaknesses of the police shooting training system seems to be a very necessary activity. It is necessary to find answers to questions, how to make it shape in a way that comprehensively meets the expectations and intentions of the policemen themselves, as to their security and citizens' sense of protection, not forgetting criminals and effectively eliminating their criminogenic activity, through the effective use of firearms.

\section{The Form of Shooting Training}

Polish Police Forces' shooting training since the 1990s has almost an invariable form (Zarządzenie nr 10/97; Zarządzenie nr 5/2000; Decyzja nr 713). Shooting with short firearms is carried out on several levels. The first of them is preparatory shooting, which consists of shooting shots, in unlimited time, to a white sheet of paper without any graphic signs. The purpose of this form of training is to introduce and familiarize the policeman with the characteristics of the phenomenon of the shot itself and the accompanying elements, such as: bang of a shot, toss and recoil of weapons or mechanics of its operation. In connection with the above, there is no particular expectation in relation to a policeman realizing this type of shooting, except for a few bullets in the area of the aforementioned piece of paper. Preparatory shooting is carried out only in police schools, as part of basic vocational training, in which freshly appointed policemen take part, often without any former contact with firearms. 
The next level of shooting training is static shooting, often referred to as precision shooting. The characteristics of this form of shooting practice is similar to that of preparatory shooting - no time limit, but the goal is already determined. The targets are various types of shields, including the TS2 shield, or ring disc, whose pattern is derived from sport shooting. During this type of training, the student is expected to obtain the best focus, resulting in a shot closest to the centre of the target. The shooter learns how to work properly on the trigger tongue and skilfully align the sights.

Passing successfully the first stages of shooting training, officers perform further types of shooting, such as: fast, dynamic, situational shooting. In fast shooting, the target is the so-called silhouette shields, and the shooting time is limited. Dynamic shooting combines elements of rapid shooting with additional diversification in the form of adding a symbolic physical effort before shooting. Most often it is a run of up to several dozen meters or deflection of arms in the front support, so-called pumps. Situational shooting is characterized by the introduction of shields showing silhouettes of neutral people who are not a threat and are not the target for the shooter. Under time pressure, the shooter must properly recognize the target and conduct fire so effectively and accurately as not to damage the area of neutral targets. In addition, these shooting can be enriched with such elements as the use of covers, reduced visibility on the shooting range, the use of flashlights to illuminate targets, or work in a team. The form of shooting training was regulated by decision No. 713 of the Police Commander in Chief of December 30, 2005 on the shooting training of policemen (Decyzja nr 713 2005).

It would seem that this organized training course for shooters prepares officers in the field of using firearms on a high-level. Nevertheless, the multiplicity and characteristics of events occurring in the territory of the country with the use of firearms by police officers, shows serious shortcomings of the current one, it is worth adding - a form of training which has not been evolving for years.

The first element that should be discussed is the interpretation of ensuring security for police officers during shooting training. As it is commonly known, the safety of classes is a very important and inseparable element of the training, and the obligation to ensure it rests at the shooting instructor. Thanks to the following of an appropriate safety framework, accidents, such as the shooting of another participant, during the training are very rare. However, when looking from the other side, the major restrictions related to security mean that the police officers taking part in the training are in some 
way incapacitated, limited, and released from a certain responsibility for the activities performed. This leads to situations in which a policeman who takes part in shooting at a shooting range cannot be guided by his own will or intuition, but has clearly indicated where to stand charging ammunition, where to move, where to fire or whether to do it in the march or is the leading hand to be held freely down the body or on the grip of the weapon. In addition, after the actual shooting, the participant is relieved even when checking the state of charge of his own weapon. Such a predetermined frame of elements that a police officer can perform and which he is not allowed to, even though they appear to be safe, they limit the ability of the policeman to act independently during the real action with the use of a weapon.

Another controversial aspect are the conditions prevailing at police shooting ranges. At most firing ranges, the firing of a fire, regardless of its standing, kneeling or lying position, is only possible straight ahead, towards the positioned bullet trap. This limits the practice of other possibilities and variants associated with shooting with a variable angle, e.g. up and down. In addition, during shooting training, it is assumed that the policeman is the first to shoot, and as it is well-known, the situation may be reversed on the spot and the policeman may be under fire. In such situations, every human being, not only a police officer, instinctively searches for a way to protect himself from a gunshot, and then the policeman is able to implement the procedure of using a firearm. In the system of Polish training, there is a lack of training elements that can take place during real situations at the crime scene.

The form of the policeman's service often generates situations in which the firearm should be used in a non-standard manner, which cannot be implemented by conducting training on the basis of applicable regulations. The specifics of the policeman's service creates circumstances in which he must act quickly using his weapon in an instant manner, such as shooting from within the vehicle. On a daily basis, most policemen travel during service with police cars. Unfortunately, the above-mentioned decision of the Police Commander in Charge regarding shooting training does not provide for learning how to shoot from a vehicle or to a vehicle, how to leave a vehicle in a situation of fire, or what parts of the vehicle can be used for effective protection during a shootout. Unfortunately, this leads to the fact that during the real use of weapons with the use of a car, police officers are largely doomed to their own instinct, cunning, the ability to keep cold blood and creativity. 
The situation of the learner studying according to strictly defined procedures can be easily illustrated by a metaphor comparing him to a student of a football school. Just as he will not become a good player, he who only shoots penalty on goal alone, so even the best policeman will not be a good shooter from a tactical point of view, practicing only shooting paper targets. Just as a student needs to play a few matches, acquire good manners, become familiar with the phenomenon of a foul or lead a ball against players of an opponent team, the policeman needs to practice the acquired shooting skills in conditions close to real ones.

The creation of a training system, which more closely reflects the real use of firearms, can significantly increase the level of shooting skills and develop in the policeman the ability to make decisions independently in a very stressful situation, which is the use of firearms. As shown by the research of Dutch scientists (Nieuwenhuys, Oudejans 2011), policemen training under pressure, under conditions of fear, obtained better results in the short and long term in the accuracy of shooting, and their reaction time, acquisition and reloading of weapons was shorter. Oudejans (2008) in his research he compared two ways of conducting training: in the first the policemen trained on cardboard shields, in the second one with a real opponent who could also shoot. The first training method used is decisively similar to the form of training conducted in Poland.

The conclusion from the research clearly confirmed that training requiring an increased level of fear may acclimate the policeman to real situations that may be encountered in his professional work, which are accompanied by an increased level of stress. Future training of officers should include a greater variety of situational scenarios than those that are present in current training, exposing course participants to possible variants of each event. They should educate the officer in the ability to adapt to the situation, as well as create confidence in their own intuition and ability in the decision-making process (Harris et al. 2017).

\section{Policemen' Individual Predispositions (Mental and Physical)}

Due to the need to preserve the universal and unified nature of shooting training, the personality traits and individual predispositions of police officers are not usually taken into consideration when organizing trainings. The question arises as to how important they are when using the skills acquired by the police in practice. 
In the GDMS (General Decision-Making Style) questionnaire, which is often used to assess the preferences of the choices of police officers due to the fact that it was designed using, among others, military personnel, in its characteristics of work in some respects similar to the police, there are five styles of decision making: rational (accurate search and logical assessment), intuitive (reliance on intuitions), dependent (seeking advice), avoiding (tendency to delay) and spontaneous (directness) (Scott, Bruce 1995; Gambetti et al. 2008).

Individual preference for each style varies from high to low, and decision-making can be based on many styles; however, for each person, one style tends to dominate. Two types dominating in the police, most in line with the attitude of the officer: rational and intuitive, have been subjected to research related to the comparison of the type and time of making a decision to use the weapon and consequences of its use (Mitchell, Flin 2007; Brown, Daus 2015).

In their work, Shanique G. Brown and Catherine S. Daus (2015) state that a greater impact than the individual personality traits of individuals, have trainings and drills completed by the police officers, working out their movement memory. However, they pay attention to several factors that have not been included in the research, such as, for example, analyses taking into account the country of origin of policemen, and which may be an obstacle to the generalization of results. Similar conclusions were drawn by Lucy Mitchell and Rhona Flin (2007), who confirmed that the shooting or failure to shoot a suspect during the simulator experiment was closely related to the use of training methods rather than the impulse resulting from individual characteristics.

Police officers rely heavily on the so-called quick thinking, which is often dictated by the fast pace of action at the crime scene. The use of this element during trainings, especially using the scenario of a stressful situation, could become an invaluable component encouraging a policeman to intuitively act in a way to resolve a conflict or situation being the subject of intervention and actions taken by him. Greater confidence in your own intuition can reduce stress related to making decisions and increase their effectiveness in performing activities. In addition, training aimed at controlling emotions, such as anger, can especially bear fruit in increased and high risk situations (Brown, Daus 2015).

Regardless of the level of individual psychological and physical predispositions of police officers, frequent and wisely composed training in the use of firearms will result 
in a uniformly high level of ability to use it, and hence - professional, safe and effective conduct of interventions with a high level of risk.

\section{Summary}

The high level of safety is undoubtedly a strong point of the currently functioning training system in the Polish police, which is indicated by a small number of accidents at shooting ranges. During the training, the policemen are provided with the comfort of exercising in conditions that guarantee their protection. However, the form of shooting training in the Polish police has been unchanged for many years, and therefore their effectiveness would require thorough, thorough verification. According to the results of scientific research conducted in the area of training of police officers, in order to be able to develop and constantly improve, an appropriate, modern training model should be adapted, which would definitely go beyond the framework of template and reproductive habits, very limited in its form. Introducing trainings that would reflect real situations that a policeman can face during his service would help to significantly improve the level of preparation of police officers for the various situations in which they may be. It seems that this is the right direction of change that should be considered in the future planning of shooting training.

In addition, one should not stress only the highest attendance of police officers on shooting training, but also take into account the personality factor, such as intuition or the ability to cope with high risk situations. Building officers' confidence in their own skills and intuition can become invaluable in a dangerous situation.

\section{References}

Aronson E. (1997), Człowiek istota - spoteczna, Warszawa, Wydawnictwo Naukowe PWN Bohdziewicz P. (2013), Szkolenie i doskonalenie zawodowe w policii: inwestycja w kapitat ludzki czy biurokratyczna ucią̇liwość? „Acta Universitatis Lodziensis”, Folia Oeconomica 288 Brown S.G., Daus C.S. (2015), The influence of police officers' decision-making style and anger control on responses to work scenarios, "Journal of Applied Research in Memory and Cognition" Vol. 4 (3) 
Decyzja nr 713 Komendanta Głównego Policji z dnia 30 grudnia 2005 w sprawie szkolenia strzeleckiego policjantów (2005), https://www.infor.pl/akt-prawny/U27.2006 .003 .0000009 , metryka,decyzja-nr-713-komendanta-glownego-policji-w-sprawieszkolenia-strzeleckiego-policjantow.html

Dworzecki J. (2011). Wspótczesne modele sžolenia policyjnego w RP jako element rapobiegania dysfunkcjom w pełnieniu stu̇̉by. Zeszyt Naukowy Wyższej Szkoły Bezpieczeństwa Publicznego i Indywidualnego w Krakowie „Apeiron”, No. 6

Gambetti E., Fabbri M., Bensi L., Tonetti L. (2008), A contribution to the Italian validation of the General Decision-making Style Inventory, „Personality and Individual Differences” Vol. 44 (4)

Gołdyka L., Markowska D., Stankiewicz J. (1999), Socjologia: pojecia, teorie, problemy, Zielona Góra, Wydawnictwo Politechniki Zielonogórskiej

Harris K.R., Eccles D.W., Freeman C., Ward P. (2017), 'Gun! Gun! Gun!': An exploration of law enforcement officers' decision-making and coping under stress during actual events, „Ergonomics" Vol. 60 (8)

Hofreiter L. (2013), Roz̨ważania nad bezpiecz̧eństwem, „Securitologia” Vol. 1 (17)

Klich J. (2016). Rola szkoleń w rozwoju kapitału ludzkiego Policji na praykkładzie komendy powiatowej, „Zeszyty Naukowe Wyższej Szkoły Humanitas. Zarządzanie” No. (1)

Martyniak-Mróz B. (2007), S ¿kolenia w Policji po nowemu, „Kwartalnik Policyjny” No. 2

Maslow A.H. (1943), A Theory of Human Motivation, „Psychological Review” Vol. 50 (4)

Mitchell L., Flin R. (2007), Shooting decisions by police firearms officers, „Journal of Cognitive Engineering and Decision Making" Vol. 1 (4)

Nieuwenhuys A., Oudejans R.R. (2011), Training with anxiety: short-and long-term effects on police officers' shooting behavior under pressure, „Cognitive processing” Vol. 12 (3)

Oudejans R.R.D. (2008), Reality-based practice under pressure improves handgun shooting performance of police officers, „Ergonomics” Vol. 51 (3)

Scott S.G., Bruce R.A. (1995), Decision-making style: The development and assessment of a new measure, „Educational and Psychological Measurement” Vol. 55 (5)

Statystyka - Policja, portal Policja.pl, Wybrane statystyki, Broń, http://statystyka.policja.pl/st/wybrane-statystyki/bron [1.08.2018]

Ustawa z dnia 6 kwietnia 1990 r. o Policji, Dz.U. z 2017 r. poz. 2067, 2405, z 2018 r. poz. 106, 138, 416, 650, 730, 1039, 1544, 1669

Walt S. (1987), The Origins of Alliances, Ithaca, Cornell University Press 
Wytyczne nr 1 Dyrektora Biura Kadr, Szkolenia i Obsługi Prawnej Komendy Głównej Policji z dnia 20 listopada 2017 roku w sprawie określenia zakresy, zasad i przebiegu szkolenia strzeleckiego oraz trybu i organizacji sprawdzianów strzeleckich w 2018 roku (2018)

Zarządzenie nr 10/97 Komendanta Głównego Policji z dnia 2 kwietnia 1997 w sprawie szkolenia strzeleckiego policjantów (1997)

Zarządzenie nr 5/2000 Komendanta Głównego Policji z dnia 30 marca 2000 zmieniajace zarządzenie w sprawie szkolenia strzeleckiego policjantów (2000) 